\title{
Structure and tectonic evolution of hybrid thick- and thin-skinned systems in the Malargüe fold-thrust belt, Neuquén basin, Argentina
}

\author{
FACUNDO FUENTES*†, BRIAN K. HORTON $\ddagger$, DANIEL STARCK $\S$ \\ \& ANDRÉS BOLL§ \\ *YPF, Macacha Güemes 515, Buenos Aires, 1106, Argentina \\ $\ddagger$ Department of Geological Sciences and Institute for Geophysics, Jackson School of Geosciences, University of Texas \\ at Austin, Austin, Texas, 78712, USA \\ $\S$ Tecpetrol, Della Paolera 299, Buenos Aires, Argentina
}

(Received 24 November 2015; accepted 24 May 2016; first published online 25 July 2016)

\begin{abstract}
Andean Cenozoic shortening within the Malargüe fold-thrust belt of west-central Argentina has been dominated by basement faults largely influenced by pre-existing Mesozoic rift structures of the Neuquén basin system. The basement contractional structures, however, diverge from many classic inversion geometries in that they formed large hanging-wall anticlines with steeply dipping frontal forelimbs and structural relief in the order of several kilometres. During Cenozoic E-W shortening, the reactivated basement faults propagated into cover strata, feeding slip to shallow thrust systems that were later carried in piggyback fashion above newly formed basement structures, yielding complex thickand thin-skinned structural relationships. In the adjacent foreland, Cenozoic clastic strata recorded the broad kinematic evolution of the fold-thrust belt. We present a set of structural cross-sections supported by regional surface maps and industry seismic and well data, along with new stratigraphic information for associated Neogene synorogenic foreland basin fill. Collectively, these results provide important constraints on the temporal and geometric linkages between the deeper basement faults (including both reactivated and newly formed structures) and shallow thin-skinned thrust systems, which, in turn, offer insights for the understanding of hydrocarbon systems in the actively explored Neuquén region of the Andean orogenic belt.
\end{abstract}

Keywords: Andes, Argentina, fold-thrust belt, foreland basin, inversion, hydrocarbons.

\section{Introduction}

The structural framework of the Malargüe segment of the Andean fold-thrust belt ( $\left.34-36^{\circ} \mathrm{S}\right)$ provides essential insights into the hydrocarbon systems of the northern part of the prolific Neuquén basin system of Argentina. Although both thick- and thin-skinned structures have been long recognized during the past decades of exploration and discovery of several important hydrocarbon fields (Giampaoli, Ramirez \& Gait, 2005; Boll et al. 2014), the complex geometric and kinematic evolution of the Malargüe fold-thrust belt (MFTB) remains a key issue in the varied reconstructions of the Andean and pre-Andean geologic history. Regional geological mapping, 2D seismic acquisition and exploration wells enabled the first modern understanding of the major structural elements of the MFTB (Mombrú \& Bettini, 1975; Kozlowski, Baldi \& Mancilla, 1981; Kozlowski, 1984; Kozlowski et al. 1989; Ploskiewicz, 1987, 1993; Ploskiewicz \& Gorroño, 1988). These efforts largely preceded the widespread understanding of tectonic inversion and potential geometric and kinematic links between thick- and thin-skinned thrust systems (e.g. Williams, Powell \& Cooper, 1989; Cooper et al. 1995;

$\nmid$ †uthor for correspondence: facundo.fuentes@ypf.com
McClay, 1995; Kley et al. 2005; Perez et al. 2016, this issue). In recent years, the MFTB has received renewed attention, with significant debate focused on two main issues: (1) the relative timing and relationships between thin- and thick-skinned systems; and (2) the potential importance of inversion tectonics as the principal mode of Cenozoic Andean deformation (Manceda \& Figueroa, 1995; Giambiagi et al. 2008, 2009; Turienzo, 2010; Kraemer et al. 2011; Mescua \& Giambiagi, 2012; Turienzo et al. 2012). Considerable discussion has focused on the northern zone of the MFTB where enhanced exhumation has exposed deeper structural levels. In this paper, we build on the large body of previous work by generating a series of structural cross-sections and providing interpretation of some critical, potentially overlooked structural relationships that yield insights into the understanding of this complex hybrid thick- and thin-skinned segment of the Andean orogenic belt. Important further constraints come from re-evaluation of key map relationships at a local and regional scale, with support from $2 \mathrm{D}$ and $3 \mathrm{D}$ seismic reflection data. In turn, the geometry, kinematic interactions and relative timing of both thick- and thin-skinned thrust systems are important for the ongoing hydrocarbon exploration in the Neuquén basin, and shed light on previously discovered 


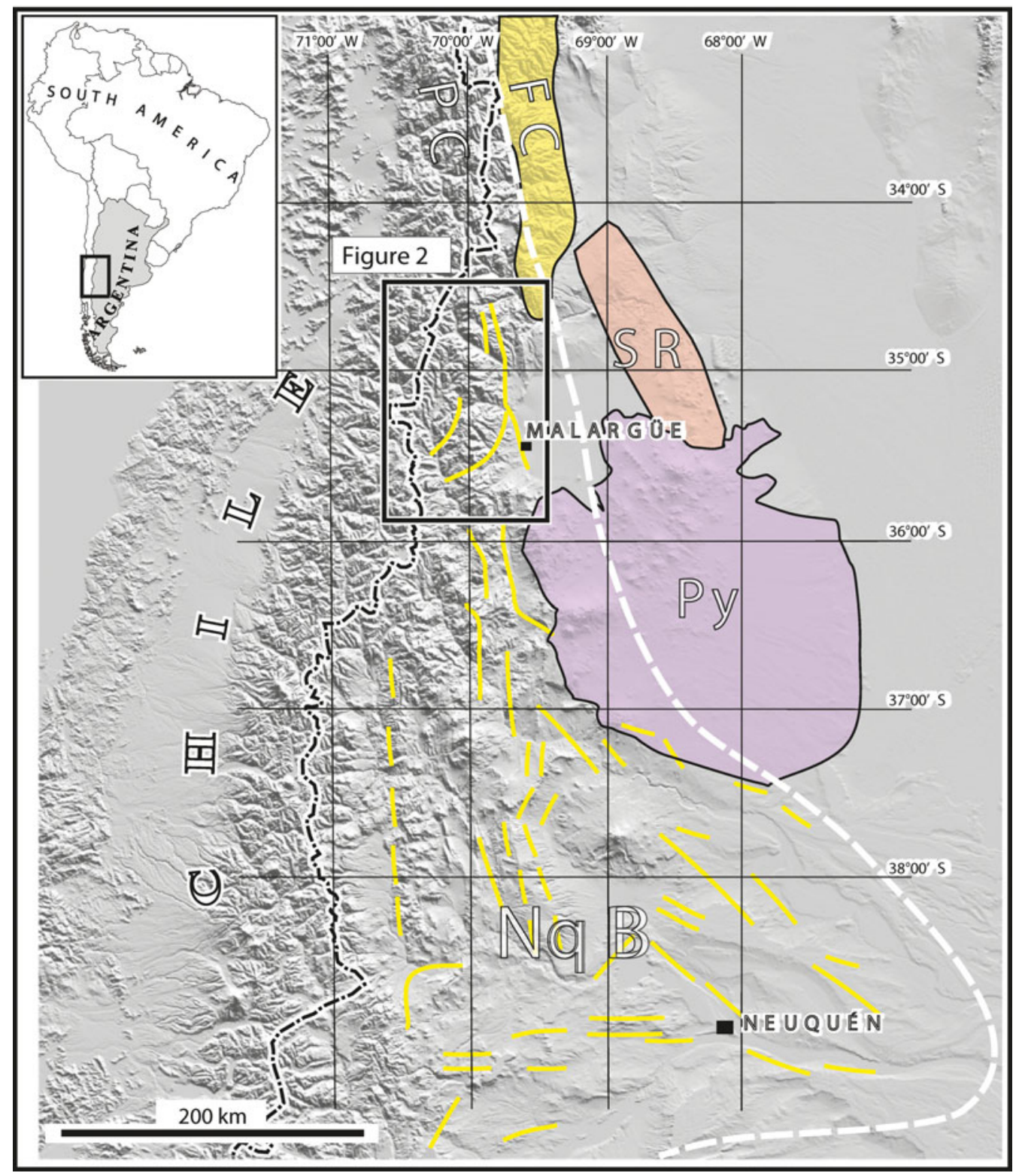

Figure 1. (Colour online) Shaded relief map of the Andes at $33-40^{\circ} \mathrm{S}$ showing regional tectonic elements (PC - Principal Cordillera; FC - Frontal Cordillera; SR - San Rafael block; Py - Payenia volcanic field; NqB - Neuquén basin) and location of geologic map of the Malargüe fold-thrust belt (box outline, Fig. 2). Extensional faults of Late Triassic - Early Jurassic age (short line segments) in the Neuquén basin are simplified from previous work: south of $36^{\circ} \mathrm{S}$ (Vergani et al. 1995), north of $36^{\circ} \mathrm{S}$ (Manceda \& Figueroa, 1995; Bechis et al. 2010).

but poorly understood components of the petroleum system.

\section{Regional geologic setting}

The N-trending MFTB is constructed principally of Mesozoic-Cenozoic sedimentary and older basement rocks of the narrow, $\mathrm{N}$-trending segment of the northern Neuquén basin system (Figs 1,2). The Neuquén basin was initiated as a back-arc basin during latest Triassic extension, producing fault-bounded depocentres with N-S-, NW-SE- and ENE-WSW-trending orientations (Digregorio et al. 1984; Legarreta \& Uliana, 1991; Vergani et al. 1995). Latest Triassic - Early Jurassic back-arc extension was followed by Middle Jurassic - Early Cretaceous thermal subsidence (sag phase), with punctuated inversion events (Vergani et al. 1995), and subsequent Andean Late Cretaceous - Cenozoic shortening.

The MFTB belongs to the Principal Cordillera, the westernmost of the classic morphotectonic zones of western Argentina (e.g. Ramos, Cegarra \& Cristallini, 1996). The easternmost morphotectonic zone, the Frontal Cordillera, is defined by the Carrizalito range, a major basement structure that plunges southwards into the subsurface beneath Cenozoic synorogenic strata adjacent to the northernmost MFTB (Figs 13 ). The region is currently situated above a $30^{\circ} \mathrm{E}$ dipping segment of the subducted Nazca plate, with the Pampean flat-slab region located $\sim 200 \mathrm{~km}$ further north (Ramos, 1999). The total E-W distance from the trench to the frontal (external) structures 


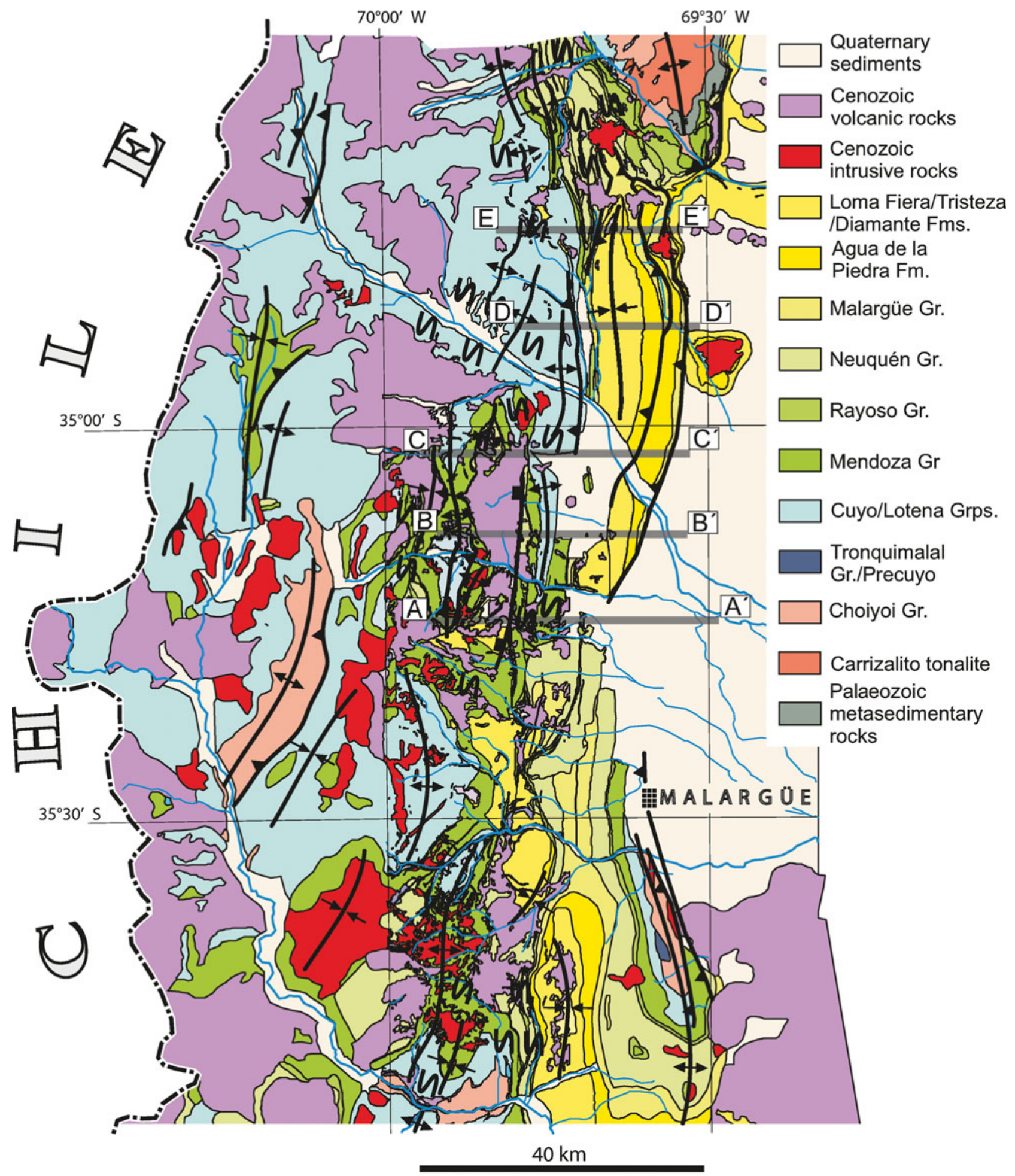

Figure 2. (Colour online) Geological map of the Malargüe fold-thrust belt showing major structures, E-W traces of cross-sections $\mathrm{A}-\mathrm{A}^{\prime}$ to $\mathrm{E}-\mathrm{E}^{\prime}$ (grey lines, Fig. 5), zones of complex deformation (wavy symbols) and localities (Fig. 3) discussed in the text (after Kozlowski, Baldi \& Mancilla, 1981; Kozlowski et al. 1989; Bechis, 2009; Turienzo, 2010).

of the easternmost MFTB foothills is in the order of $350 \mathrm{~km}$. Andean magmatism in this region constitutes a complex history of eastward migration, with important late Cenozoic magmatic centres that have sporadically invaded the foreland (Folguera \& Ramos, 2011) and potential short-lived flat-slab episodes. For example, the Payenia volcanic field (Fig. 1), a <
$5 \mathrm{Ma}$ igneous plateau, has been related to asthenospheric influx due to the steepening of the subducted Nazca plate after a proposed cycle of shallow subduction (Kay, Burns \& Copeland, 2006; Folguera et al. 2009).

Large basement-involved structures and a complex array of thin-skinned thrust systems compose the 


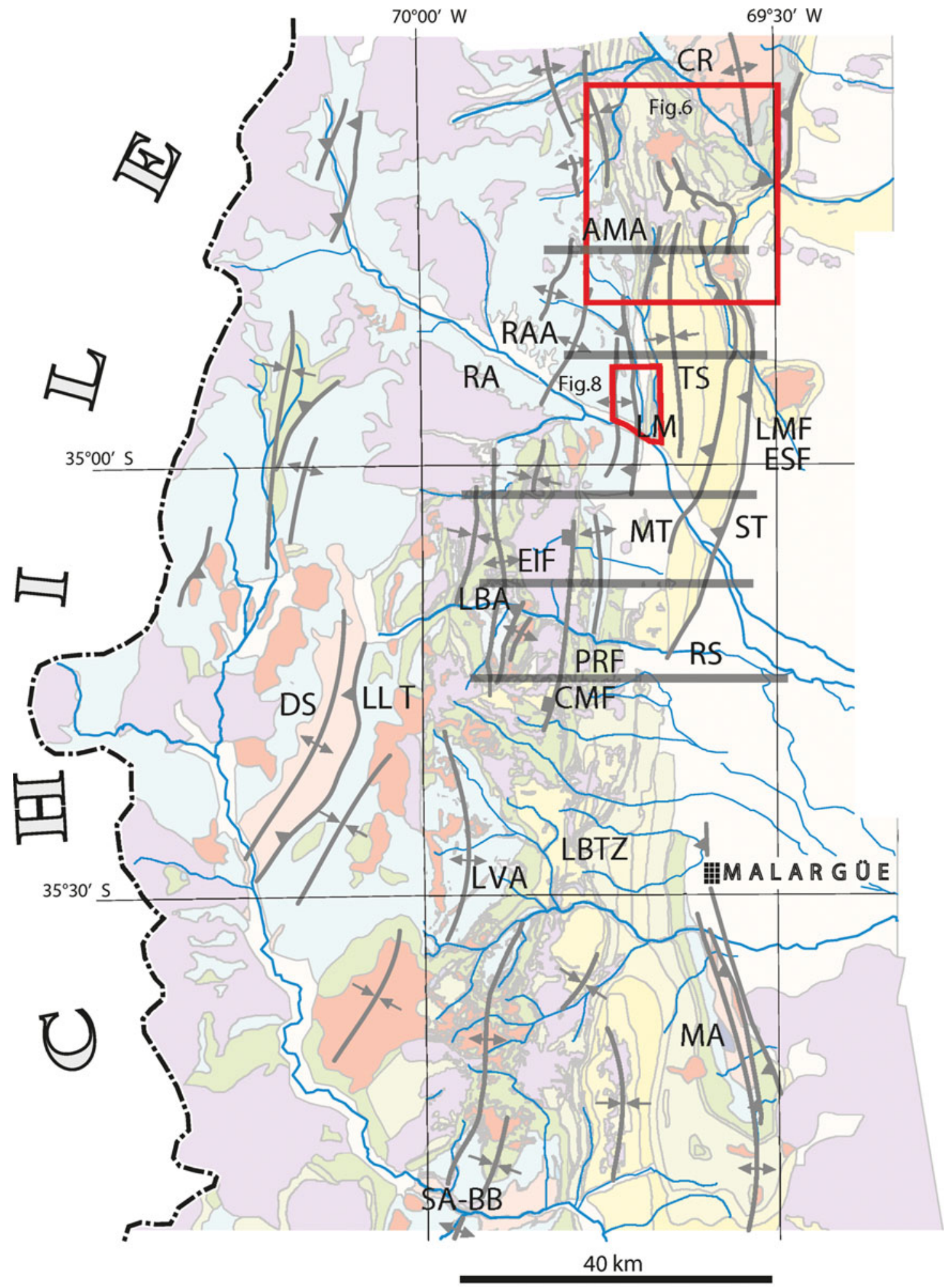

Figure 3. (Colour online) Index map of the Malargüe fold-thrust belt (comparable to Fig. 2) showing key topographic, structural and petroleum features, and location of detailed maps (Figs 6, 8). AMA - Arrollo Matancilla anticline; CMF - Cerro Mollar oilfield; CR Carrizalito range; DS - Dedos-Silla block; EIF - El Infiernillo fault; ESF - El Sosneado oilfield; LBA - Los Blancos anticline; LBTZ - La Brea triangle zone; LLT - Las Leñas thrust; LM - Loma del Medio; LMF - Loma de la Mina oilfield; LVA - La Valenciana anticline; MA - Malargüe anticline; MT - Mesón thrust; PRF - Puesto Rojas oilfield; RAA - Rio Atuel anticlinorium; RA - Rio Atuel; RS - Rio Salado; SA-BB - Sierra Azul-Bardas Blancas; ST - Sosneado thrust; TS - Tristeza syncline.

MFTB. The principally $\mathrm{N}-\mathrm{S}$ orientations of the Andean contractional basement structures closely correlate with the trend of Mesozoic extensional faults (Fig. 1), and half-graben inversion has been proposed as the main mechanism of thick-skinned deformation (Manceda \& Figueroa, 1995). The eastern part of the fold-thrust belt is characterized by large basementcored antiformal structures and outcropping or 
shallowly buried frontal thin-skinned thrust sheets (Fig. 2). In the south, south of the Rio Salado drainage, the large basement-cored Malargüe anticline persists for $\sim 50 \mathrm{~km}$ along strike. In the north, the northward along-strike projection of this basement structure is represented by the Rio Atuel anticlinorium, which exposes a thick pile of Jurassic rocks in its hanging-wall, over a comparable $\sim 50 \mathrm{~km}$ strike length (Fig. 3). East of the Rio Atuel anticlinorium, the frontal part of the thrust belt is defined by a thin-skinned thrust system involving Cenozoic foreland basin and older strata. The Tristeza syncline is situated above this frontal thrust system, defining a large-scale morphological feature $>50 \mathrm{~km}$ in length (Figs 2, 3). Andean E-W shortening calculated in this region is relatively modest, in the order of 15-30 km (Giambiagi et al. 2012), with $\sim 25 \%$ shortening values for the frontal part of the thrust belt (Giambiagi et al. 2008; Turienzo, 2010). Mean topographic elevations along the MFTB range between 2 and $3.5 \mathrm{~km}$ (Giambiagi et al. 2012).

The region is distinctive in that it preserves a complete record of the Andean foreland basin system, which has been largely exhumed and eroded along most of the Neuquén basin. To the east, the San Rafael block, a low-relief major basement structure oblique to the thrust belt, has been related to foreland uplifts such as the Sierras Pampeanas further north. The San Rafael basement block uplift separates the Neuquén basin from the Triassic depocentre of the General Alvear subbasin to the east and has been attributed to the proposed Payenia phase of shallow subduction (Folguera et al. 2015). The San Rafael block may act as an erosional barrier, helping preserve the Cenozoic basin fill from large-scale exhumation related to headward erosion of foreland drainage systems.

\section{Stratigraphic framework}

The Mesozoic-Cenozoic stratigraphic succession of the Neuquén basin (Fig. 4) was mostly developed on top of Permo-Triassic igneous rocks of the Choiyoi Group, and underlying metasedimentary and low-grade metamorphic Palaeozoic rocks. The widespread Choiyoi Group makes up the bulk of the uppermost mechanical basement, as shown by the thick panels exposed in the Carrizalito range, Dedos-Silla structure, Malargüe anticline, and to the east in the San Rafael block (Figs 1,2). The Choiyoi Group is composed of extrusive and intrusive acidic to mesosilicic igneous rocks, and associated non-marine clastic deposits. Along the southern termination of the Frontal Cordillera, in the Splunging Carrizalito range, lower Palaeozoic metasedimentary rocks are intruded and overlapped by Choiyoi Group rocks (Volkheimer, 1978; Tickyj et al. 2009). Mesozoic-Cenozoic basin evolution is recorded by: (1) Upper Triassic to Lower Jurassic rift deposits; (2) Middle Jurassic - Lower Cretaceous sag deposits; and (3) Upper Cretaceous - Cenozoic foreland basin deposits.
Evidence of earliest basin evolution in the region is locally preserved along the Malargüe anticline, where remnants of Triassic rift-related strata crop out as the Chihuiu, Llantenes and Remoredo formations (Artabe et al. 1998). To the north, synextensional deposits recording the early stages of the Neuquén basin development include the Arroyo Malo, El Freno and Puesto Araya formations (Lanés et al. 2008). Upsection, the Pliensbachian-Callovian upper part of the Cuyo Group comprises a number of units, including offshore mudstones, marine sandstones and evaporites of the Tres Esquinas, Lajas and Tábanos formations, respectively, whose accommodation was influenced by former riftrelated structures. Aeolian deposits of the Callovian Lotena Formation, and carbonates and evaporites of the Oxfordian La Manga and Auquilco formations make up the Lotena Group (Gulisano \& Gutiérrez Pleimling, 1994). The Lotena and lower units are only present in the west. In the foreland platform to the east, the Kimmeridgian Tordillo Formation onlaps Choiyoi basement, as shown by exploration wells and seismic data (e.g. Giambiagi et al. 2008; Boll et al. 2014). The Tordillo Formation is mostly characterized by fluvial and aeolian strata with abrupt lateral thickness changes. The overlying Tithonian Vaca Muerta Formation has marked facies changes from coastal facies in the eastern platform (Legarreta, Kozlowski \& Boll, 1981) to thick marine shales with high total organic carbon (TOC) values in the Rio Atuel anticlinorium to the west (Boll et al. 2014). The thin Valanginian Chachao limestone separates the Vaca Muerta from the Agrio Formation, which also shows facies changes from coastal deposits in the east to offshore marine marls in the west. The Aptian-Albian Rayoso Group contains the Huitrín and Rayoso formations, with mixed clastic, limestone and evaporite facies.

A basin-scale unconformity (the 'Intersenoniana' unconformity) separates the underlying succession from the thick clastic deposits of the Neuquén Group. This unit has very coarse facies locally, and thicknesses vary from $900 \mathrm{~m}$ in the west to $<100 \mathrm{~m}$ in the eastern platform. The Neuquén Group has been interpreted as the oldest stratigraphic unit related to initial shortening and foreland flexural subsidence (Ramos \& Folguera, 2005; Tunik et al. 2010; Fennell et al. 2015).

The overlying Malargüe Group is composed of the Loncoche, Roca, Pircala and Coihueco formations (Legarreta, Kokogian \& Boggetti, 1989). The Loncoche Formation consists of dark mudstone and is capped by thin limestones of the Roca Formation. The Pircala and Coihueco formations are dominated by mudstone with minor sandstone. Regionally, the Malargüe Group is markedly tabular, with uniform thicknesses in the order of 600 to $700 \mathrm{~m}$.

A protracted regional unconformity, of roughly $20 \mathrm{Myr}$ duration, separates the fine-grained Coihueco Formation (uppermost Malargüe Group) from the overlying coarser Agua de la Piedra Formation and younger units (Horton \& Fuentes, 2016). The Agua de la Piedra is the first unit that is considered to be 


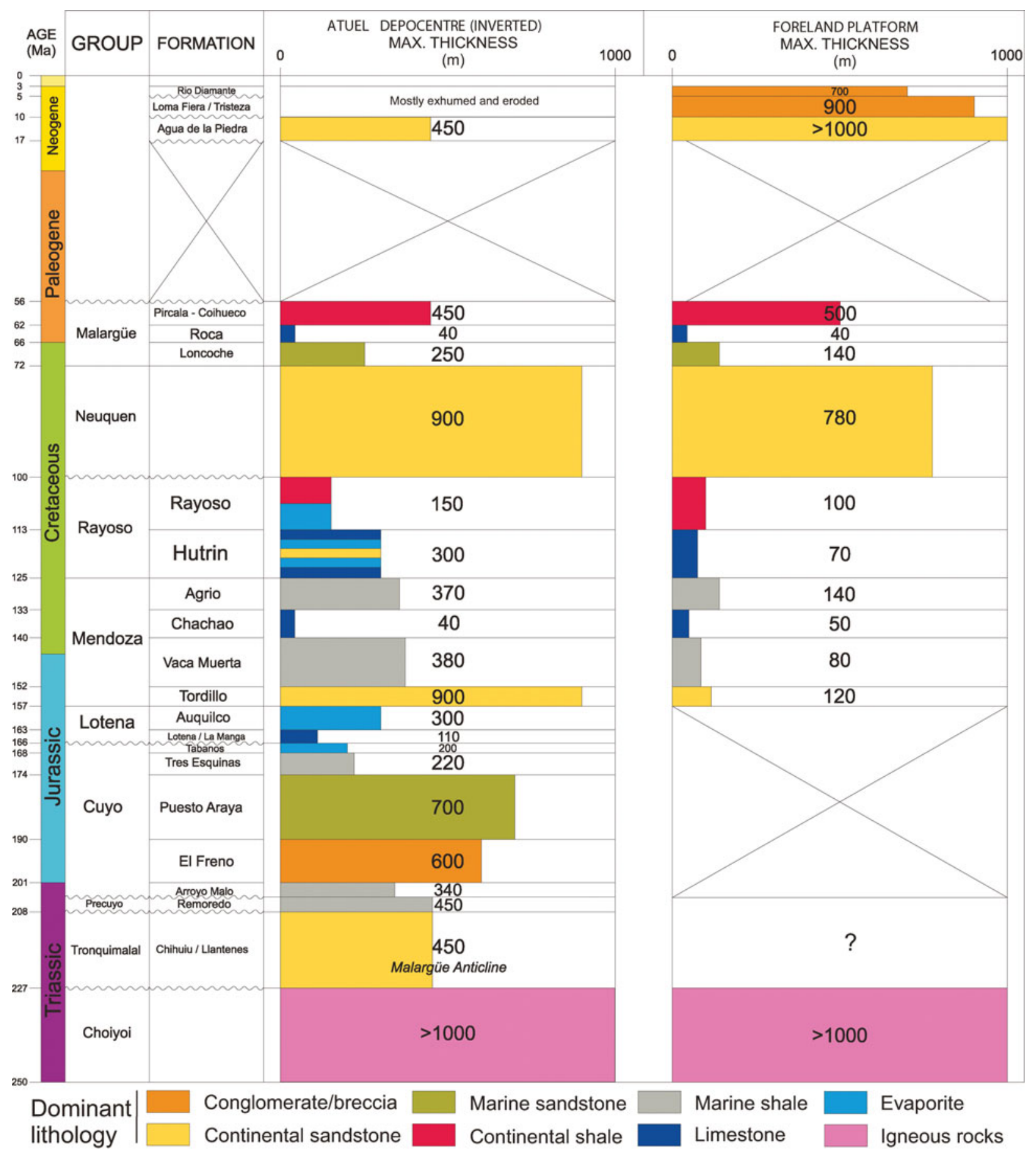

Figure 4. (Colour online) Upper Palaeozoic through Cenozoic stratigraphic charts showing pronounced thickness variations between the Atuel depocentre (west) and the foreland platform (east).

an unambiguous synorogenic deposit generated during Andean shortening. Exploration wells indicate a thickness up to $\sim 1500 \mathrm{~m}$, with fluvial and subordinate aeolian deposits. Upsection, volcaniclastic debris-flow deposits of the Loma Fiera Formation record proximal volcanic sources and high topographic gradients. This unit grades vertically and laterally into finer and more distal facies of the Tristeza Formation, with thicknesses up to $900 \mathrm{~m}$ according to well data, which is overlain by Pliocene and Pleistocene deposits of the Diamante and Los Mesones formations.

\section{Structural geology}

The MFTB is characterized by large basement structures (Manceda \& Figueroa, 1995; Giambiagi et al. 2008, 2009; Turienzo, 2010; Turienzo et al. 2012) and thin-skinned thrusts systems developed both on top of these basement structures and along the eastern thrust front, as revealed by regional map relationships (Fig. 2) and five new E-W cross-sections (Fig. 5). From east to west, the general structural framework includes: (1) a mostly undeformed foreland platform with thin 


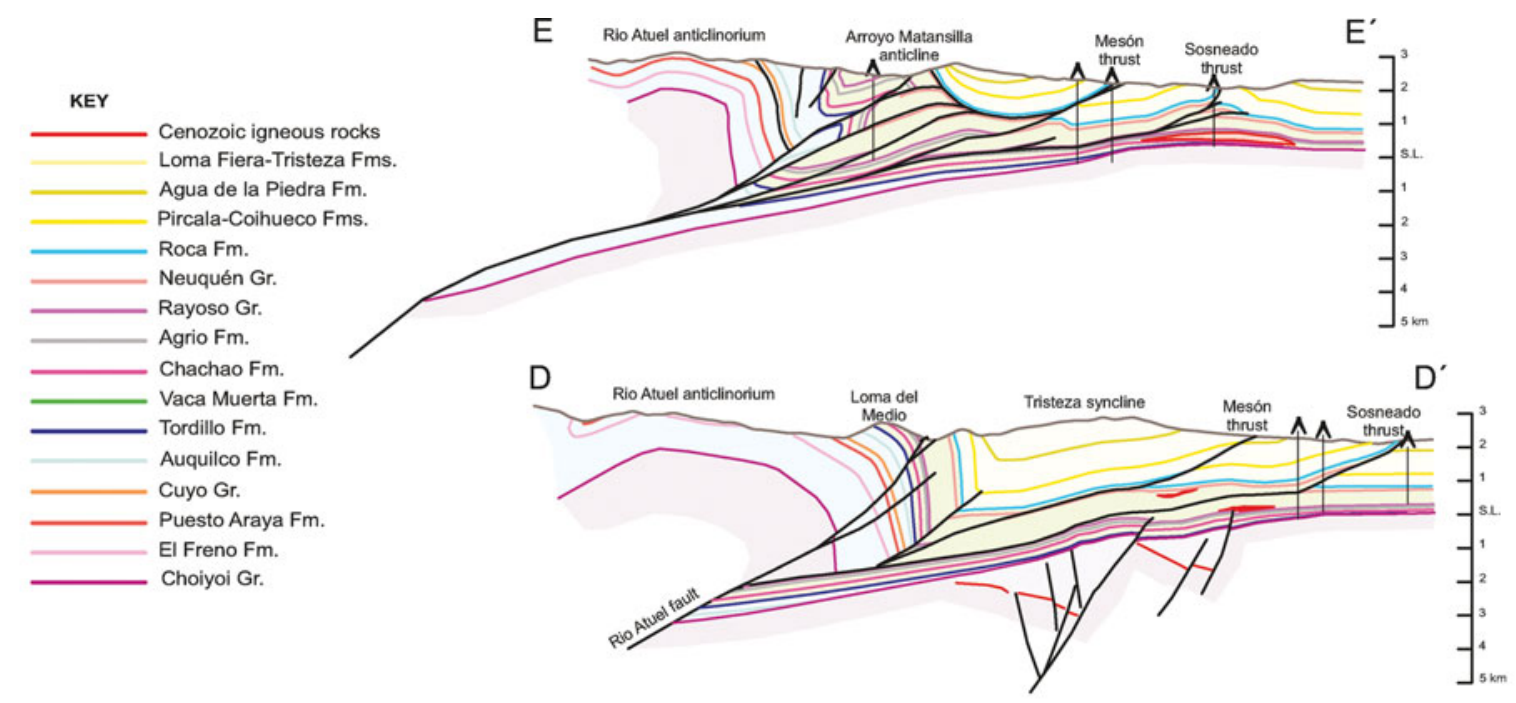

C
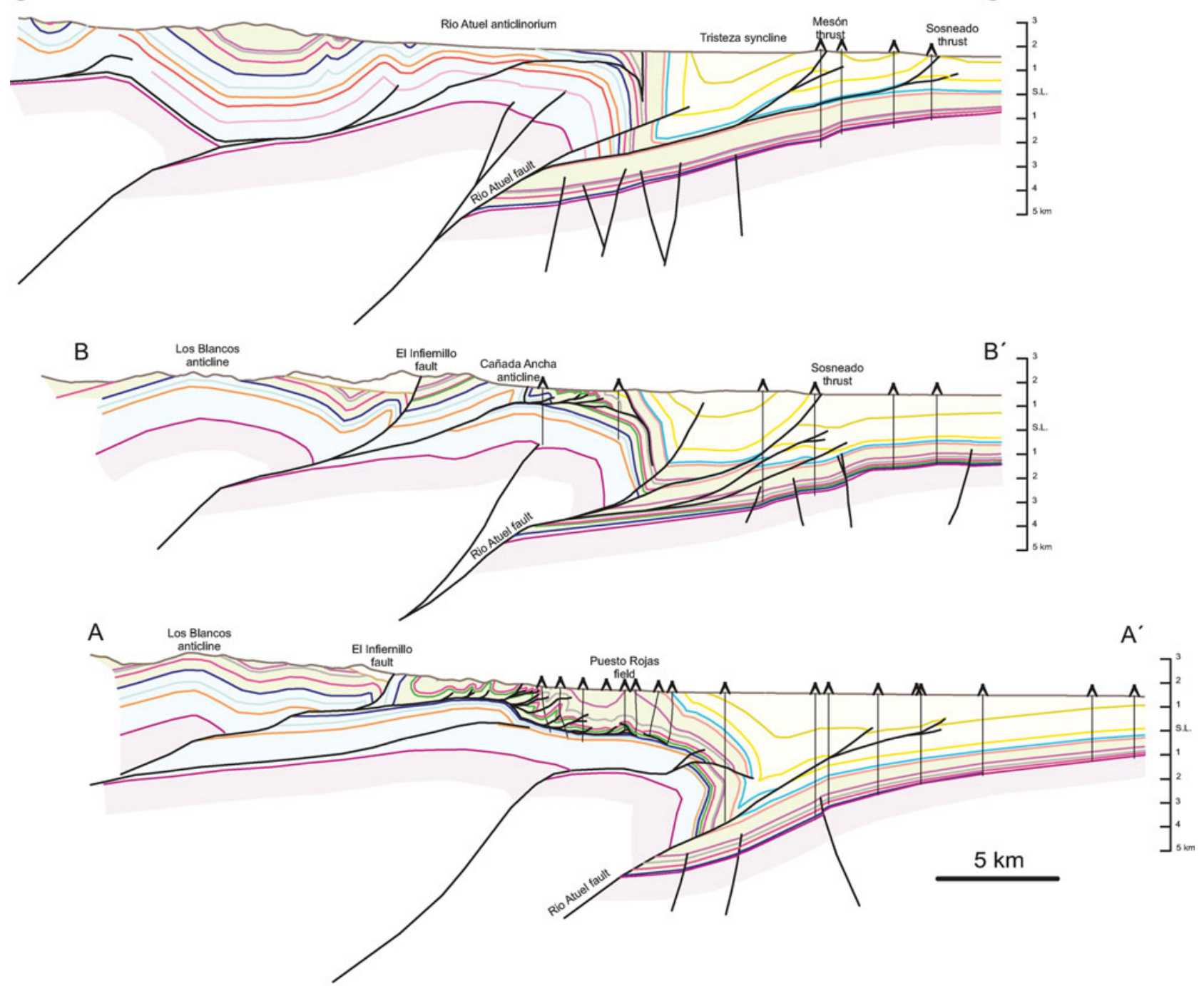

Figure 5. (Colour online) E-W structural cross-sections A- $\mathrm{A}^{\prime}$ to $\mathrm{E}-\mathrm{E}^{\prime}$ of the Malargüe fold-thrust belt at $34.75^{\circ} \mathrm{S}$ to $35.25^{\circ} \mathrm{S}$ (see locations in Figs 2, 3).

Mesozoic deposits, covered by a thick pile of Cenozoic synorogenic sediments; (2) the S-plunging Carrizalito range of the Frontal Cordillera; (3) a frontal thrust system, including the Sosneado and Mesón thrusts, and a series of smaller blind thrusts; (4) large basement structures of the Malargüe anticline and Rio Atuel anticlinorium; (5) complex thin-skinned structures capping the Malargüe and Rio Atuel basement structures; and (6) a western hinterland region showing a complex array of both thick- and thin-skinned structures. 


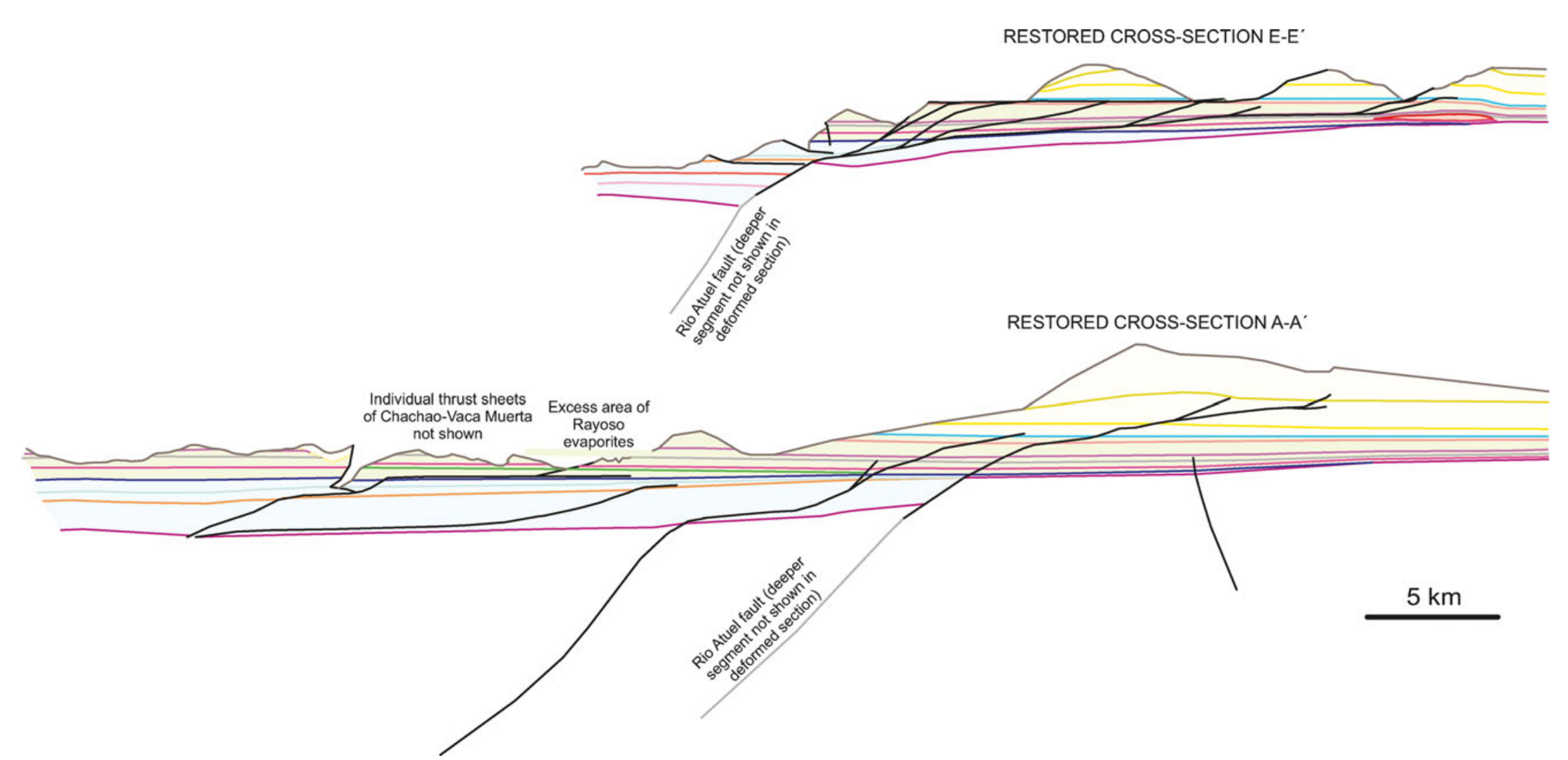

Figure 5. (Continued) (Colour online) Palinspastic restorations of cross-sections $\mathrm{A}-\mathrm{A}^{\prime}$ and $\mathrm{E}-\mathrm{E}^{\prime}$. 
The structure of the foreland platform is known from extensive 2D and 3D seismic reflection data. Most structures consist of low-displacement basement faults, some of which show subtle inversion due to Andean contractional deformation (Boll et al. 2014). These basement faults show principally N-S orientations, with additional NE- and NW-striking set orientations, and an origin related to the TriassicJurassic extension (Bechis et al. 2010; Boll et al. 2014). Along strike to the north, the foreland platform intersects the S-plunging Carrizalito range of the Frontal Cordillera. Structural reconstructions by Turienzo (2010) show a thrust fault detached at depths of $\sim 10 \mathrm{~km}$, with related basement folding that can be traced to the south into the subsurface.

The easternmost thrust systems include the Mesón, Sosneado and additional smaller-offset thrusts that carry Cenozoic foreland basin strata and underlying, relatively thin Mesozoic units (Figs 2, 3, 5). The large Tristeza syncline is the combined product of these thrust faults cutting upsection to the east, along with the folding in the forelimb of the Rio Atuel anticlinorium (Fig. 3). The surface trace of the Sosneado thrust continues for $\sim 60 \mathrm{~km}$ in a N-S direction and shows a persistent hanging-wall flat in mudstones of the lower Cenozoic Pircala and Coihueco formations (Figs 2, 5). To the north, the fault progressively cuts down-section along a low-angle lateral ramp, eventually detaching from the Rayoso Group and underlying units (crosssections D- $\mathrm{D}^{\prime}$ and $\mathrm{E}-\mathrm{E}^{\prime}$ of Fig. 5). Seismic data and fault geometric reconstructions (Giambiagi et al. 2008, their fig. 8) suggest that the Sosneado thrust connects at depth with the Rio Atuel basement fault. To the west, the Mesón thrust gains displacement north of the town of El Sosneado, and shows a low-angle hangingwall ramp cutting the Cenozoic Agua de la Piedra, Coihueco and Pircala formations that merges into a flat in the uppermost Cretaceous Loncoche Formation of the Malargüe Group. Further north, the Sosneado and Mesón thrusts detach from different units, leaving the thick and mechanically resistant Upper Cretaceous Neuquén Group in between.

These structural relationships are consistent with the generation of a large duplex system to the north (crosssection $\mathrm{E}-\mathrm{E}^{\prime}$ ), which has been largely overlooked in previous work but is outlined in detail below. The interpreted structural reconstruction of this duplex system is based on three main observations. First, geological relationships north of the Tristeza syncline (Fig. 6, Kozlowski et al. 1989) show a thrust system repeating multiple slices of the Neuquén Group. These thrust slices appear to continue to the south within the Tristeza syncline, but are obscured by overlapping Neogene to Quaternary deposits. Second, the Arroyo Matansilla anticline, west of the Tristeza syncline, shows Upper Jurassic - Cretaceous Mendoza, Rayoso and Neuquén group rocks more than $2.5 \mathrm{~km}$ above their regional elevation, but the Neuquén Group exhibits no stratigraphic separation from the overlying Loncoche Formation (cross-section E-E'). Third, the Arroyo Matansilla exploration well encountered four stacked thrust sheets, including the structure of the Arroyo Matansilla anticline. Collectively, the thrust branching relationships deduced from geologic maps (i.e. thrust sheets repeating Neuquén Group slices branching out below the Malargüe Group in the Tristeza syncline), the stratigraphic separation in front of the Arroyo Matansilla anticline, and the existence of repeated thrust sheets at the surface and in the Arroyo Matansilla subsurface support the interpretation of a duplex system with a roof thrust in the Loncoche Formation and horses involving the Neuquén Group and lower units. This duplex system involving Cretaceous rocks is exhumed to the north, affording a down-plunge view from north to south. This interpretation is detailed in geometric reconstructions of section E-E' (Fig. 5). The reconstruction differs substantially from that of Turienzo (2010), along his section $\mathrm{S}-\mathrm{S}^{\prime}$, which interprets the Arroyo Matansilla anticline as being thrust over the Tristeza syncline, despite the lack of stratigraphic separation and the aforementioned constraints.

Both the Mesón and Sosneado thrusts are frontal splays of the basement fault system beneath the Rio Atuel anticlinorium (Fig. 5). The Rio Atuel anticlinorium and the correlative Malargüe anticline are the two dominant structures of the frontal basement domain in this region (Figs 2, 3). The Malargüe anticline is breached such that the Permo-Triassic Choiyoi Group is exposed along its core and in the hangingwall of a large fault splay (Kraemer et al. 2011). Along strike to the NNW, the Rio Atuel anticlinorium exposes Lower Jurassic units, but no Choiyoi basement rocks. The basement fault carrying the Rio Atuel anticlinorium has been referred to as the La Manga fault (e.g. Giambiagi et al. 2008); however, we prefer to match the fault name with the transported hangingwall block (i.e. Rio Atuel fault). In this scheme, the exposed La Manga and Arroyo Blanco faults (Giambiagi et al. 2008) within the Loma del Medio locality represent shortcut splays of the larger Rio Atuel fault.

Debate persists over whether or not the Rio Atuel anticlinorium is produced by Cenozoic contractional reactivation (inversion) of a Mesozoic rift-related structure. Structural models by Turienzo (2010) and Turienzo et al. (2012) neglected inversion tectonics, and instead showed a stacked system of large basement thrust slices. In contrast, Giambiagi et al. (2008) proposed models of inverted half-graben structures that fed slip eastwards into the frontal thin-skinned systems, similar to our interpretation. Subsurface data provide several critical constraints indicating the presence of synrift deposits in the hanging walls of basement structures, but also reveal important along-strike variations. Whereas subsurface data east of the Rio Atuel anticlinorium show that the Choiyoi Group is covered by a thin panel of Kimmeridgian Tordillo Formation (e.g. Boll et al. 2014), atop the anticlinorium there is a thick (at least $1500 \mathrm{~m}$ ) pile of Lower-Middle Jurassic deposits in which wells have not reached the basement (Fig. 5). Part of this thick Jurassic succession 


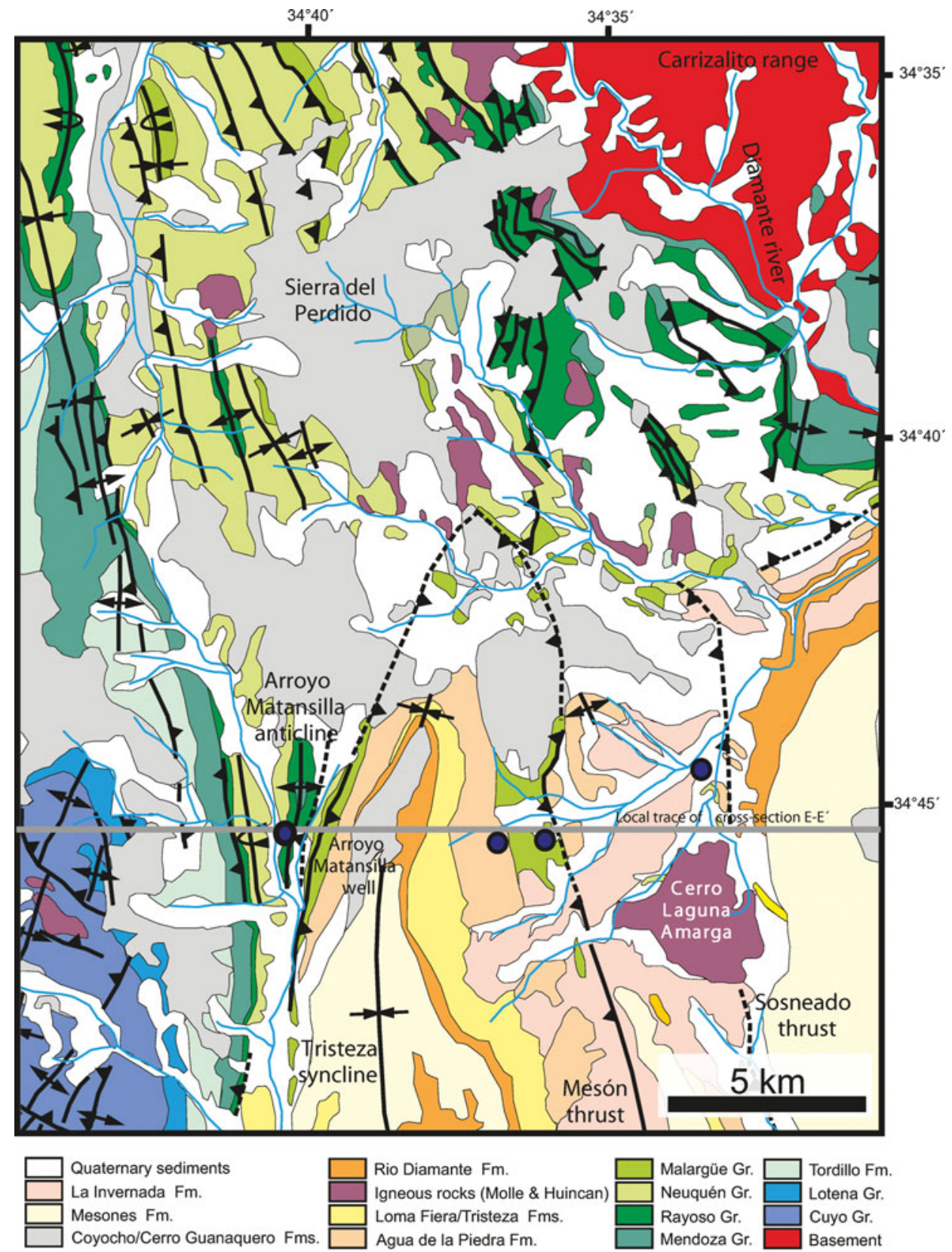

Figure 6. (Colour online) Geological map of the region north of Cuchilla de la Tristeza (simplified from Bechis, 2009, after Kozlowski, Baldi \& Mancilla, 1981) showing key relationships along E-W cross-section E-E' (grey line; Fig. 5). Our interpretation of the northern segment of the Mesón thrust differs from previous maps in that it forms a roof thrust of the Arroyo Matansilla duplex system to the north and west. Thrust sheets (or exhumed horses) repeating panels of the Neuquén Group are buried beneath Neogene to Quaternary deposits of the Sierra del Perdido, but likely have branch lines at depth connecting with the Mesón thrust.

consists of coarse fan-delta facies and turbidite deposits, likely associated with syndepositional extensional faults (Lanés et al. 2008). In the south, the Malargüe anticline only shows local Triassic rift deposits (Kraemer et al. 2011) and relatively thin Jurassic units; nevertheless, this structure appears to be related to inversion of the Rio Atuel extensional depocentre. A structural map of the top of the Choiyoi Group based on our crosssections, cross-sections along the Malargüe anticline (Kraemer et al. 2011) and well data from the foreland (Fig. 7) confirms a genetic link between the Rio Atuel and Malargüe antiforms. Our preferred explanation is that both of these basement-involved structures can be related to an extensional fault system that accumulated volumetrically important synrift deposits along the present location of the Rio Atuel anticlinorium and must have tipped out to the south.

Our analysis, and past interpretations of seismic data (e.g. Giambiagi et al. 2008; Kraemer et al. 2011; Boll et al. 2014), constrain the position of footwall cutoffs for basement (Choiyoi Group) and overlying units, and the deep ramp geometry responsible for the Rio Atuel basement hanging-wall anticline (Figs 5, 7). The position of the autochthonous footwall cutoffs is fur- 


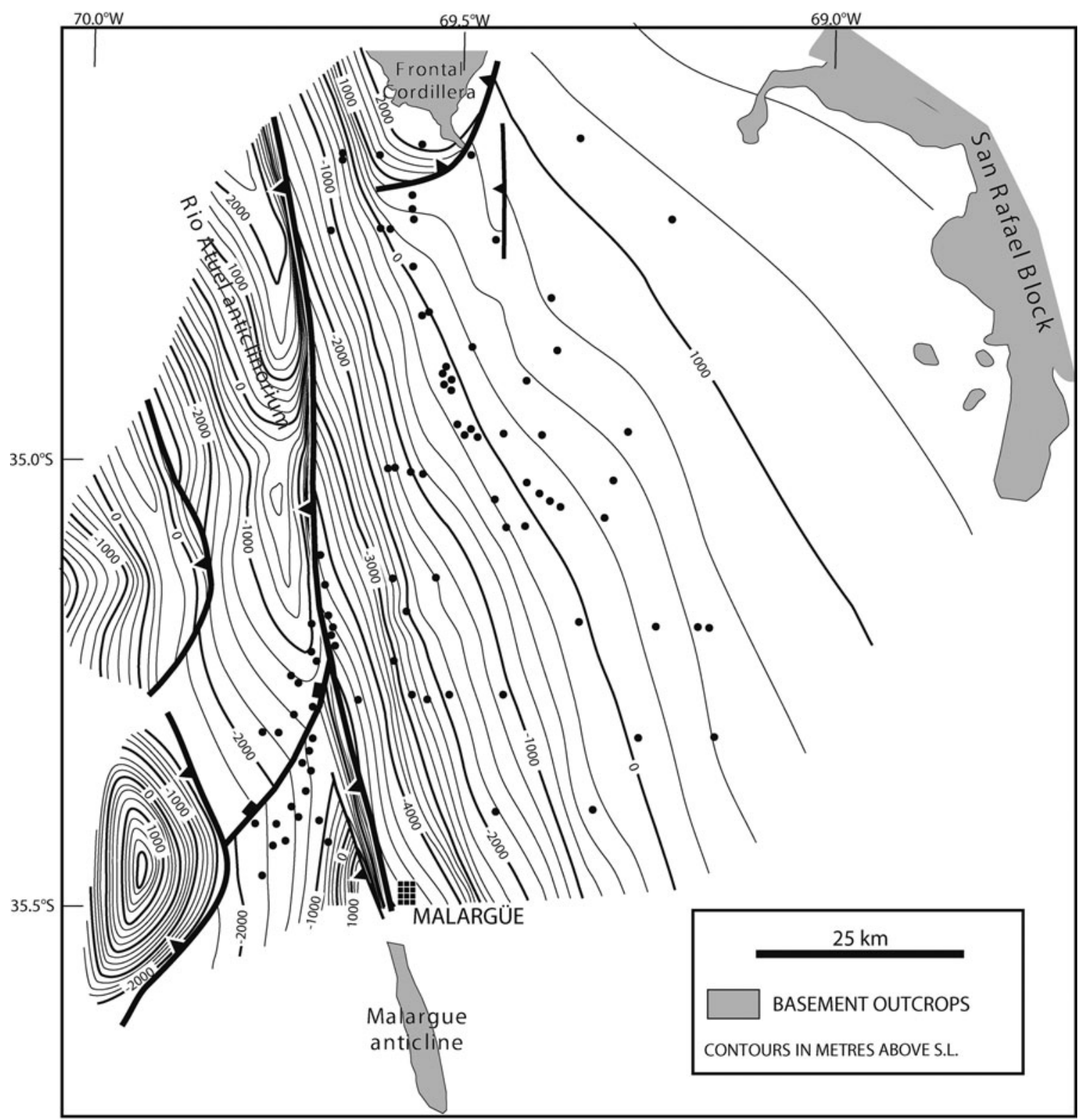

Figure 7. Structural map of the top of the basement (including the Permian-Triassic Choiyoi Group and older rocks), showing the basement-cover interface in metres above sea level, derived from our cross-sections, a cross-section for the Malargüe anticline (Kraemer et al. 2011) and well data.

ther constrained by the amount of shortening recorded by structures to the east. The position of these cutoff lines is of importance for potential source rock maturation beneath the Rio Atuel structure, as explained below.

A complex array of thin-skinned structures distinguish the top of the Rio Atuel basement structure. The Puesto Rojas oil field (cross-section A-A' of Fig. 5) produces hydrocarbons from several horses of a duplex system defined by a lower detachment in the Vaca Muerta shale and a roof detachment in evaporites of the Rayoso Group. The evaporites are tectonically thickened along the front of this shallow thrust system (Ploskiewicz \& Gorroño, 1988; Giampaoli, Ramirez \& Gait, 2005). To the west, complex trailing structures of the Puesto Rojas thrust system are exhumed (Dajczgewand, 2002) (Fig. 5). The eastward extent of this shallow duplex thrust system coincides with marked changes in facies and thickness both in Vaca Muerta and Rayoso deposits, which localize the floor and roof thrusts, respectively. Thick, detachment-prone shales of the organic-rich Vaca Muerta Formation are controlled in turn by greater subsidence due to the Rio Atuel extensional fault system (Boll et al. 2014). Along the foreland platform, the Vaca Muerta grades laterally eastward into greenish siltstones of more proximal deposystems. A similar trend is expressed within the Rayoso evaporites, which pinch out to the east, and whose deposition seems to have been controlled by the Atuel depocentre. These relationships suggest that the location of the shallow duplex and triangle zone was controlled by facies changes originally dictated by the contrasting Mesozoic subsidence regimes east and west of the rift-related fault system (Fig. 4). Development of 
this shallow duplex system probably occurred during earlier shortening, before contractional reactivation of the Rio Atuel fault, such that the floor detachment was later lifted and tilted into its present E-dipping configuration (cross-section $\mathrm{A}-\mathrm{A}^{\prime}$ of Fig. 5). Therefore, following its development, the whole duplex system was lifted and exhumed along the Rio Atuel inverted block. Shortening along this shallow thrust system can be linked with growth of the Los Blancos anticline to the west (Fig. 5), a basement-cored inversion anticline (see Manceda \& Figueroa, 1995). Inversion of the Los Blancos structure fed slip eastwards into Jurassic units, with thrusts eventually climbing upsection to shallow levels creating the Puesto Rojas and related duplex structures.

A possible highly exhumed analogue is present $~$ $40 \mathrm{~km}$ north of Puesto Rojas, in the Loma del Medio area (Fig. 8) west of the Arroyo Blanco. Here, Lower Jurassic Puesto Araya sandstones are in thrust contact with Oxfordian Auquilco anhydrite in the footwall. To the east, near-vertical beds of the Tordillo and Vaca Muerta formations define the eastern flank of the Rio Atuel anticlinorium, which is capped by highly deformed thrust slices of the Huitrín Formation stacked beneath mostly undeformed Rayoso evaporites. These relationships are overprinted by a number of late shortcut faults that omitted sections in an already vertical to steeply overturned panel of deformed strata. This structural scenario is similar to that of the Puesto Rojas field, with the only difference being the younger stratigraphic units involved in the shallow thrust system (i.e. Huitrin rather than Chachao-Agrio formations). In map view, the spatial gap between the thrust trace of Puesto Araya on Auquilco strata and the basal thrust of the stacked Huitrín carbonate slices can be considered a tectonic window. Thus, the Auquilco, Tordillo, Vaca Muerta and the thrust-omitted Agrio formations represent exhumed footwall rocks. The regional importance of this system is that (1) it provides a genetic link to the Puesto Rojas duplex system, over a $\sim 40 \mathrm{~km}$ strike distance, and (2) it provides important kinematic constraints in that the shallow duplex system must pre-date inversion and uplift of the deep Rio Atuel structure. Although we identify here the kinematic linkage of the frontal exhumed duplex horses with a trailing thrust further west, and the intervening tectonic window, the first recognition of a duplex system later tilted to its current subvertical position belongs to Dimieri, Fortunatti \& Nullo (2005).

Shortening estimates along our cross-sections (Fig. 5) range from $\sim 14.5 \mathrm{~km}$ in the south (crosssection $\mathrm{A}-\mathrm{A}^{\prime}$ ) to $\sim 13.9 \mathrm{~km}$ in the north (cross-section $\left.\mathrm{E}-\mathrm{E}^{\prime}\right)$. The shortening value for the southern crosssection includes the Los Blancos anticline, duplex structures of the Puesto Rojas area, and the Rio Atuel anticlinorium and structures along its front. The northern cross-section involves the Rio Atuel anticlinorium and all structures along its front. Calculated shortening values are remarkably similar to those presented by Giambiagi et al. (2008) near our cross-section C- $\mathrm{C}^{\prime}$ and by Turienzo (2010) near our northernmost crosssection E-E' (Fig. 5).

Two distinctive characteristics of the inverted basement structures of the MFTB are noteworthy. First, these structures all have steeply dipping forelimbs that are in the order of $4 \mathrm{~km}$ of structural relief (Fig. 5). This geometry is uncommon in many inversion structures, which tend to form the classic harpoon shapes (e.g. Williams, Powell \& Cooper, 1989; McClay, 1995). The detailed geometry of these steeply dipping to overturned forelimbs is well constrained by outcrop and subsurface data, with several exploration wells drilled in front of basement structures that navigated along steep flanks for $>3 \mathrm{~km}$. Surface structural data along these forelimbs show consistent steeply dipping to overturned panels, whereas seismic data show an abrupt lack of information restricted to a relatively narrow zone that matches with the subvertical beds constrained by wells and surface information. This deformation geometry seems to be shared by other basement anticlines not clearly related to inversion of large extensional depocentres, including the Sierra Azul-Bardas Blancas and several other structures further south (Manceda \& Figueroa, 1995; Giambiagi et al. 2009). The mechanics behind this mode of deformation remain poorly understood, but may be influenced by the composition and anisotropies within the regional basement, the Choiyoi Group and underlying units, whose rheology is significantly different than more homogeneous crystalline basement rocks. Second, although basement structures have a structural relief of several kilometres, the topography is limited, and the frontal inverted structures have particularly subtle topographic expression. For example, the Rio Atuel anticlinorium records $\sim 4-5 \mathrm{~km}$ of structural inversion (as constrained by restoration of the top of Choiyoi basement to its original post-rift position) yet shows only a modest shift in topography (Fig. 5). This apparent contradiction may be resolved through assessments of the relative timing between inversion, erosion and flexural subsidence in the adjacent foreland, with the possibility that poorly consolidated sedimentary rocks on top of growing basement structures were easily eroded and deposited in foreland depocentres along the eastern front of these structures.

A further interesting point of the MFTB is the potential presence of Cenozoic extensional faults, closely post-dating Andean contractional deformation (crosssections $\mathrm{A}-\mathrm{A}^{\prime}$ and $\mathrm{B}-\mathrm{B}^{\prime}$ of Fig. 5). The W-dipping El Infiernillo fault (Gerth, 1931) west of Puesto Rojas has been interpreted as a Neogene extensional fault of post-orogenic origin by Kozlowski et al. (1990). Evidence for Quaternary activity on this fault comes from basaltic lavas that have erupted along the fault (Ramos $\&$ Kay, 2006). In our reconstructions, this fault is developed along a local structural culmination composed of stacked Mesozoic units, and links westward with the former basement thrust fault related to the Los Blancos anticline. Late-stage extensional collapse along similar structural culminations is well documented in the North America Cordillera (e.g. Constenius, 1996). North 


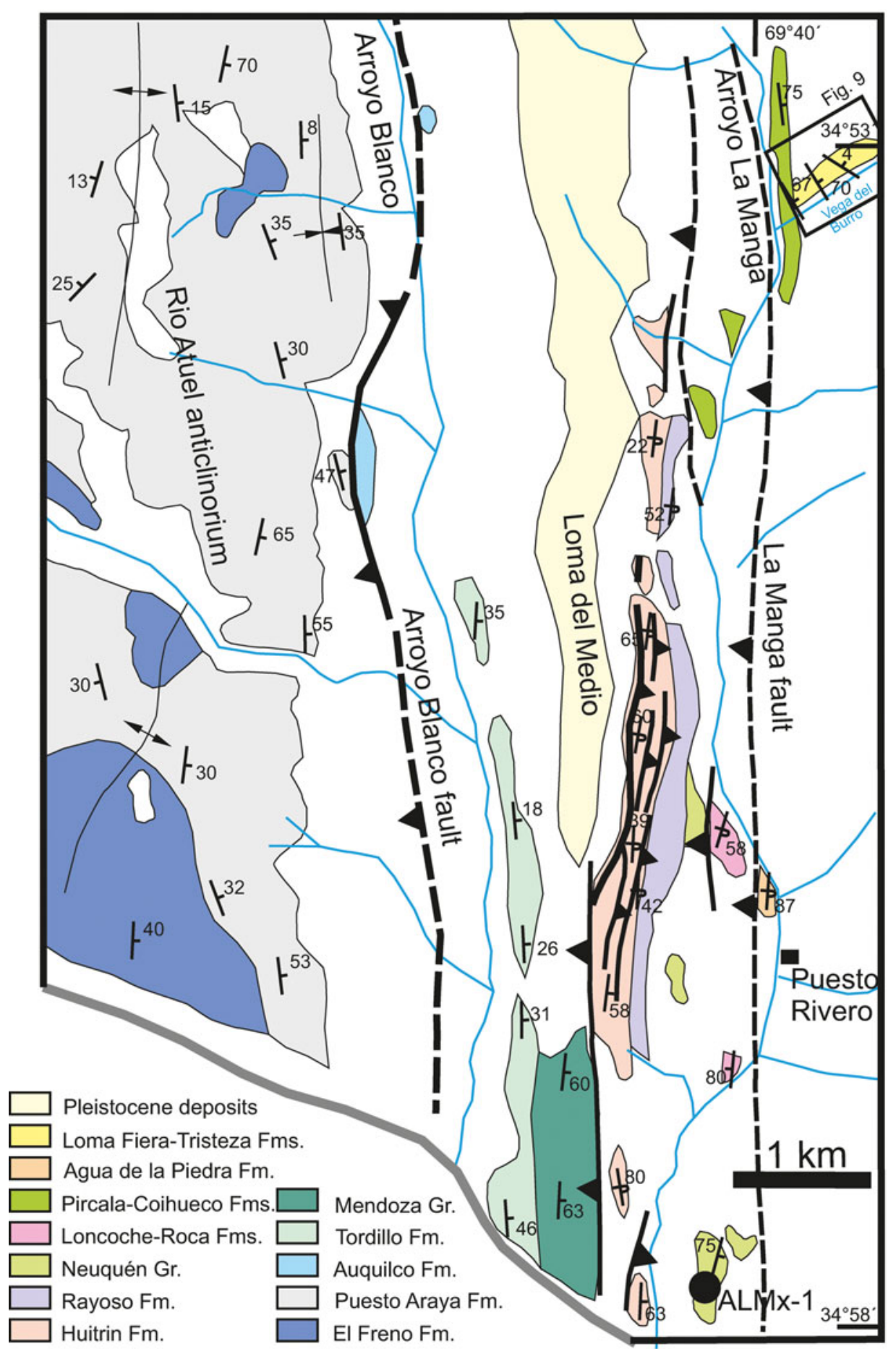

Figure 8. (Colour online) Geological map of the Loma del Medio area. The major thrust is exposed in two areas, such that the mapped western thrust trace along the Arroyo Blanco matches the eastern thrust trace at the base of Huitrín Formation to the east of Loma del Medio. Closely spaced thrusts involving the Huitrín Formation correspond to an exhumed duplex system with a roof thrust near the contact between the Huitrín and Rayoso formations. The Auquilco, Tordillo and Vaca Muerta formations form a tectonic window in the footwall of this main thrust. Further folding by inversion of the deeper Rio Atuel basement structure produced thinning in its forelimb units, and shortcut splays in an already deformed panel, generating localized stratigraphic omission. Teeth along thrust traces denote the hanging-wall block, not the fault dip or transport direction.

of Arroyo El Durazno, geological maps (Mombrú \& Bettini, 1975) show clear extensional faulting map relationships, with younger Neuquén Group hangingwall strata in fault contact with older Vaca Muerta footwall deposits, further supporting an extensional origin for the El Infiernillo fault.

\section{Kinematic evolution and synorogenic sedimentation}

Several recent studies have provided information on the timing of thrust belt deformation in this region (Giambiagi et al. 2008; Turienzo, 2010; Kraemer et al. 2011; Turienzo et al. 2012; Boll et al. 2014). The general 
consensus is that inversion of the eastern frontal structures of the basement-involved Malargüe anticline and Rio Atuel anticlinorium occurred since middle Miocene time (Giambiagi et al. 2008; Kraemer et al. 2011), although 3D seismic data in the eastern foreland platform show minor movement along basement faults since Late Cretaceous and Palaeogene time (Boll et al. 2014), coeval with early shortening along morehinterland structures in the west (Kozlowski, Cruz \& Sylwan, 1997; Mescua, Giambiagi \& Ramos, 2013; Boll et al. 2014). Based on several cross-cutting relationships, Giambiagi et al. (2008) bracketed basement fault reactivation and basin inversion between 15 and $1 \mathrm{Ma}$, with maximum displacement before $8 \mathrm{Ma}$. On the basis of deformation timing from growth strata associated with the Malargüe anticline, Kraemer et al. (2011) postulated limited shortening before $7 \mathrm{Ma}$, when basement deformation accelerated along this structure. To the north, uplift of the basementinvolved Carrizalito range may have initiated later, at about $5 \mathrm{Ma}$ (Combina, Nullo \& Stephens, 1993).

Whereas the broad age of deformation along the frontal part of the MFTB is relatively well documented, the relative timing and geometric linkages between thick- and thin-skinned structures is not. Previous work focused on the interactions between basement structures and the frontal thrust systems in the foreland, including the Mesón and Sosneado thrusts (Giambiagi et al. 2008; Turienzo, 2010; Turienzo et al. 2012), but less attention has been paid to the relationships with thin-skinned thrust systems developed atop the Rio Atuel basement structure. Our structural reconstructions based on map, well and seismic data provide further constraints. The emerging pattern results in a model that does not differ from the typical behaviour of most thrust belts, with deep-seated thrusts that ramp up and transfer slip to shallower stratigraphic levels, followed by foreland propagation of new deep-seated thrust sheets that lift and carry, in piggyback fashion, the original shallow thrust systems.

The kinematic evolution can be deduced from structural relationships in cross-sections $\mathrm{A}-\mathrm{A}^{\prime}$ and $\mathrm{B}-\mathrm{B}^{\prime}$ of Figure 5, and can be extrapolated to the north. The sequence of deformation can be divided into several steps. The first phase involved basement thrusting below the Los Blancos anticline, which fed slip into Mesozoic units, creating relatively simple contractional geometries in the Jurassic section and a complexly deformed duplex system once thrusts climbed to levels above the Vaca Muerta shales. The emplacement of these later structures occurred at depth, on top of a still noninverted Rio Atuel extensional depocentre. The eastern extent of the shallow duplex system was conditioned by both the lateral change from organic-rich shale to coarser, less organic facies in Vaca Muerta, and the eastern extent of evaporites in the Huitrín Formation, which provided favourable conditions for floor and roof thrust development. The second phase involved reverse reactivation of a basement extensional fault and hanging- wall folding in the Rio Atuel structure. This passively lifted the older, thin-skinned Puesto Rojas structures, and also fed slip to the present frontal thrust system of Mesón, Sosneado and related faults. The relative timing between the Puesto Rojas structures and the Rio Atuel fault reverse motion is well constrained: well data indicate that the basal detachment of the Puesto Rojas structures now dips east, and the northern continuation of this shallow thrust system in the Loma del Medio area (Fig. 8) is presently located along the vertical to overturned frontal part of the Rio Atuel basement anticline. A relatively similar situation has been described by Kraemer et al. (2011) further south at $35.5^{\circ} \mathrm{S}$, with the shallow La Brea triangle zone developing in front of the Torrecillas and La Valenciana anticlines, before being passively deformed during development of the broader Malargüe anticline and its hanging-wall shortcut splay.

The timing of these two phases in the structural evolution of the MFTB can be assessed through analysis of surface and subsurface growth stratal successions expressed in the foreland basin fill. The younger phase of basement reactivation and associated frontal thrusting is recorded by a growth stratal succession expressed in foreland basin fill along the eastern margin of the Rio Atuel structure, in the footwall of the mapped La Manga fault (Fig. 8). Along the Vega del Burro, a tributary drainage to the larger Arroyo La Manga, a roughly $400 \mathrm{~m}$ thick exposure of the Loma Fiera-Tristeza Formation shows major variations in stratal dip (Fig. 9). Whereas the lowest levels of the succession show steeply overturned, W-dipping bedding orientations, upper levels exhibit gentle $\left(10-20^{\circ}\right)$ eastward dips. Internally, individual beds show an eastward thickening, away from the bounding structure to the west. The upsection reduction in stratal dip and internal thickness variations are contained in a narrow zone within $\sim 1 \mathrm{~km}$ of the mapped trace of the $\mathrm{La}$ Manga fault (Fig. 8). We interpret these geometric relationships as the product of synchronous fault displacement and synorogenic sedimentation during motion on the thick-skinned Rio Atuel basement structure.

The Vega del Burro growth stratal succession is dominated by disorganized, pebble to boulder conglomeratic facies with large proportions of volcaniclastic material. Nearby sources of volcanogenic materials are consistent with previously documented phases of volcanism and shallow intrusive activity (Combina \& Nullo, 2011). New zircon U-Pb geochronological analyses of two volcaniclastic horizons from lower and upper levels of the growth stratal succession yielded youngest age populations of $10.0 \pm 0.2 \mathrm{Ma}(\mathrm{n}=3$ grains) and $7.7 \pm 0.3 \mathrm{Ma}(\mathrm{n}=5$ grains $)$, respectively (Fig. 9). These relationships require that Rio Atuel basement reactivation was active during late Miocene time, with significant deformation during the broad 10.5 to $7.5 \mathrm{Ma}$ window.

The older phase of thrusting is likely recorded in comparable growth stratal geometries imaged in 


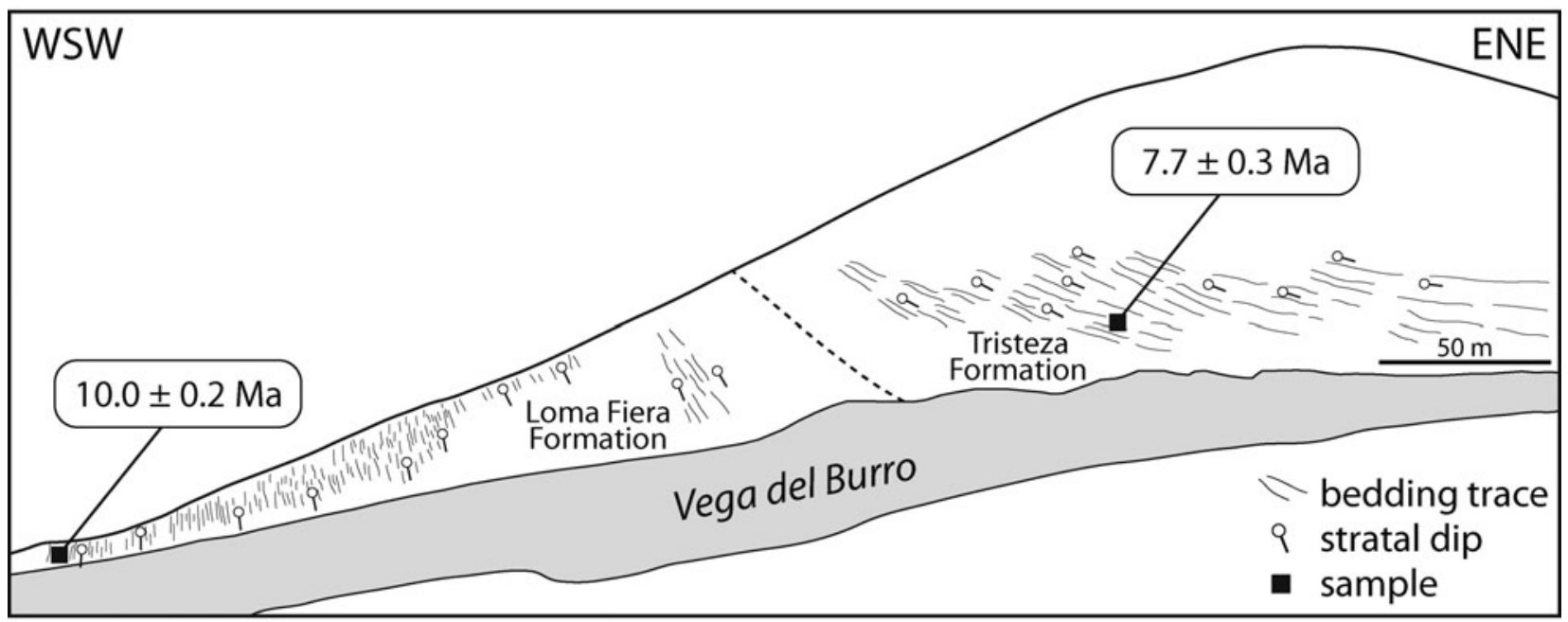

Figure 9. Schematic line drawing showing growth strata preserved in upper Miocene beds of the Loma Fiera-Tristeza Formation at the Vega de Burro locality, in the eastern footwall of the major E-directed thrust exposed in the Loma del Medio area (Fig. 8). The young zircon $\mathrm{U}-\mathrm{Pb}$ age populations from two volcaniclastic horizons provide estimates of late Miocene depositional ages and synchronous thrusting.

seismic reflection profiles and depicted in our regional cross-sections (Fig. 5). Growth relationships in the westernmost subsurface occurrences of the Agua de la Piedra Formation, along the western limb of the Tristeza syncline (Fig. 5) show pronounced eastward thickening and progressively shallower dips for higher stratigraphic levels. Rather than representing reactivation of the Rio Atuel basement structure, we suggest that these older, roughly early to middle Miocene growth relationships are the product of early displacement along the western trailing basement structure (Rio Blanco anticline) and geometrically linked displacement within the aforementioned shallow duplex system (Puestos Rojas structures).

\section{Importance for petroleum exploration}

Several hydrocarbon fields have been discovered in the MFTB and adjacent basin (Giampaoli, Ramirez \& Gait, 2005; Boll et al. 2014). Potential Jurassic-Cretaceous source rocks include the Tres Esquinas, Vaca Muerta and Agrio formations, although most current results associate the existing fields with Vaca Muerta oils (Boll et al. 2014). Within the foreland, the El Sosneado and contiguous Loma de la Mina fields total 19 million barrels of oil; further south, Llancanelo is a heavy oil field of 6 million barrels. In contrast, in the thrust belt, 35 million barrels of oil are contained within the Puesto Rojas, Cerro Mollar and several small oil fields. The foreland fields produce from subtle traps, possibly controlled by low-offset reactivated basement faults, stratigraphic traps and combined traps. These fields, however, are located away from the best source rock conditions in the Vaca Muerta, as they are along the thin, and coarser platformal zone with lean to mostly immature conditions. However, atop the Rio Atuel anticlinorium, the Vaca Muerta has optimal source rock conditions with systematic high TOC values, and maturity values reaching the oil window (Boll et al. 2014) (Fig. 10). Therefore, the migration and hydrocarbon charge of platform traps must have occurred prior to inversion of the Rio Atuel depocentre, unless generation was produced in the buried narrow strip directly east of the Vaca Muerta footwall cutoff, beneath the eastern flank of the Rio Atuel anticlinorium (Figs 5, 10). This narrow zone has not been reached by exploration wells and may have transitional facies, perhaps with generation potential. However, exploration risks in the platform would be minimized by drilling traps that existed before inversion.

For the Puesto Rojas and contiguous Cerro Mollar fields within the MFTB, the kinematic evolution and the existing geochemical data and burial history models (Boll et al. 2014) suggest that traps were likely charged prior to reverse reactivation of the Rio Atuel fault, when the shallow duplex system was deeply buried in its pre-inversion configuration. This play situation could be quite favourable, with quality source rocks and thick evaporites providing an efficient top seal for fractured reservoirs of the Chachao and Agrio formations. Subsequent exhumation due to basement uplift along the reactivated Rio Atuel fault must have been highly destructive for existing hydrocarbon accumulations, with survival of only those preserving a cover of Rayoso evaporites and sufficient closure to minimize hydrocarbon spilling. If correct, this model suggests the Puesto Rojas and Cerro Mollar fields can be considered palaeo-traps that were subsequently uplifted as part of the Rio Atuel anticlinorium during later inversion. An alternative scenario is that these thrust systems were uniformly carried close to the surface without receiving an original oil charge, but later remigration introduced fluids which converged towards the Puesto Rojas area along 


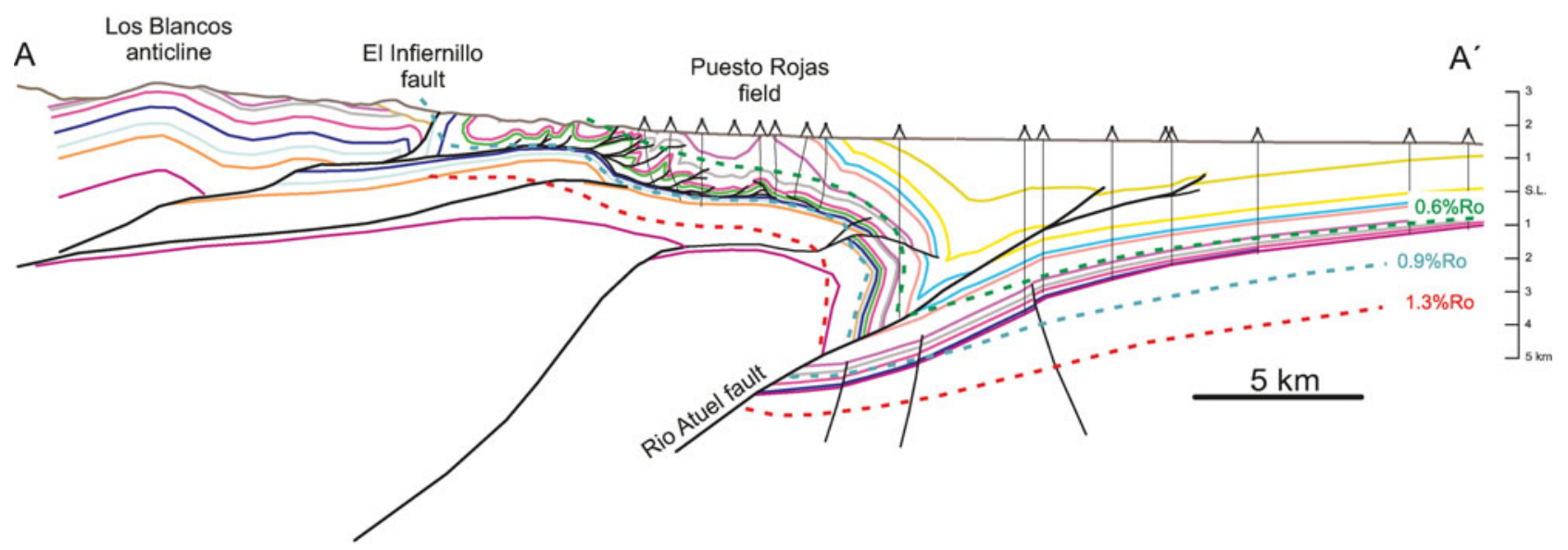

Figure 10. (Colour online) Cross-section A-A' (Fig. 5) showing vitrinite reflectance (Ro \%) values for the Puesto Rojas area and foreland platform, based on outcrop and well samples. Note the overall poor maturity (low Ro values) for the synorogenic sediments, suggestive of a low geothermal gradient.

routes defined by the structural geometry of the large anticlinorium.

\section{Conclusions}

New structural cross-sections utilizing surface maps and industry seismic and well data provide insights into the complex thick- and thin-skinned structures of the Malargüe fold-thrust belt in the Andes of west-central Argentina. Cross-cutting relationships and synorogenic deposits help in the understanding of the kinematics of the MFTB. The geometric and kinematic arguments presented here have important implications for the hydrocarbon exploration of this segment of the Andean orogenic system. Key points include the following.

(1) Cenozoic contractional structures in the MFTB were formed largely through reactivation of basementinvolved Mesozoic rift structures of the Neuquén basin system. Contrary to many examples of inversion, these structures form large hanging-wall anticlines (several kilometres of structural relief) with steeply dipping frontal forelimbs that represent a hybrid evolution involving thick- and thin-skinned geometries. Although lower structural levels record reactivation of pre-existing basement-involved normal faults, the upper levels involve linkage of inverted and newly formed faults with shallow thin-skinned fold-thrust systems involving Mesozoic-Cenozoic cover strata.

(2) The deformation style of thin-skinned thrust systems within the MFTB has been controlled by the pre-existing stratigraphic panel in front of each contractional basement fault. Frontal systems such as the Mesón, Sosneado and related thrusts represent significant faults with individual displacement of several kilometres. These eastern thrust systems developed on a thin proximal stratigraphic section of the Neuquén basin, which lacks a thick Jurassic succession and detachment-prone organic-rich shales and evaporites of the Upper Jurassic - Lower Cretaceous Mendoza and
Rayoso groups. These frontal thrusts carried Neogene foreland basin deposits, and locally include growth strata in uppermost units. In contrast, cover deformation above contractional basement faults in internal positions further west began with shortening of thick Jurassic rift-related deposits; once faults climbed upsection into the detachment-prone Vaca Muerta shales and Rayoso Group evaporites, they formed complex duplex thrust systems and triangle zones.

(3) Geometric relationships between thin- and thickskinned thrust systems provide valuable kinematic constraints for the MFTB. Trailing basement faults fed slip and shortened Jurassic-Cretaceous deposits currently capping the Atuel anticlinorium, before largescale contractional reactivation of the Rio Atuel basement fault. In this scenario, the Puesto Rojas duplex system and related triangle zones developed at depth above the non-inverted extensional fault system. The subsequent inversion of the Rio Atuel basement structure uplifted and tilted the older, shallow duplex thrust systems and triangle zones, eventually exhuming them, as in the Loma del Medio area.

(4) This several-phase tectonic history is recorded by surface and subsurface growth stratal relationships in proximal foreland basin fill. At depth, forelandward (eastward) thinning of the Agua de la Piedra Formation can be tied to roughly early-middle Miocene displacement along the trailing basement structures (Rio Blanco anticline) and affiliated shallow duplex system (Puesto Rojas thrust system). Later inversion of the leading basement structure (Rio Atuel anticlinorium) and linked frontal thin-skinned structures (Mesón and Sosneado thrusts) occurred during late Miocene time, as evidenced by 10.5-7.5 Ma growth strata in the Loma Fiera-Tristeza Formation.

(5) Foreland hydrocarbon fields were likely charged prior to inversion along the Rio Atuel structure. Vaca Muerta source rock conditions in the eastern foreland are lean and mostly immature, but are better developed to the west atop the Rio Atuel half-graben. Oil 
fields within the MFTB (Puesto Rojas and Cerro Mollar) may represent transported palaeo-traps, initially charged when thin-skinned structural traps were still at depth on top of a non-inverted Rio Atuel fault. Upon inversion, these oil fields were partially exhumed and destroyed, with local preservation of those that maintained an efficient top seal with trapping geometries and adequate closure. A less-probable alternative scenario would involve Rio Atuel fault reactivation followed by remigration along pathways controlled by this large underlying structure.

Acknowledgements. This work was partially funded by US National Science Foundation grant EAR-1348031. We thank Tecpetrol and YPF for access to proprietary data. Constructive reviews by Adrian Pfiffner, Matías Ghiglione and editor Jonas Ruh helped us improve the manuscript.

\section{References}

Artabe, A., Morel, E., Spalletti, L. \& Brea, M. 1998. Paleoambientes sedimentarios y paleoflora asociada en el Triásico tardío de Malargüe, Mendoza. Revista Asociación Geológica Argentina 53, 526-48.

BeCHIS, F. 2009. Deformación transtensiva de la Cuenca Neuquina: análisis a partir de ejemplos de campo $y$ modelos análogos. Ph.D. thesis, Facultad de Ciencias Exactas y Naturales, Departamento de Geología, Universidad de Buenos Aires, Buenos Aires, Argentina. Published thesis.

Bechis, F., Giambiagi, L., García, V., Lanes, S., CRISTALlini, E. \& TUNIK, M. 2010. Kinematic analysis of a transtensional fault system: the Atuel depocentre of the Neuquén Basin, Central Andes, Argentina. Journal of Structural Geology 32, 886-99.

Boll, A., Alonso, A., Fuentes, F., Vergara, M., LAFFitTe, G. \& Villar, H. J. 2014. Factores controlantes de las acumulaciones de hidrocarburos en el sector norte de la cuenca Neuquina, entre los ríos Diamante y Salado, Provincia de Mendoza, Argentina. In IX Congreso de Exploración y Desarrollo de Hidrocarburos, Mendoza, Argentina, Actas, pp. 3-44.

CombinA, A. \& Nullo, F. 2011. Ciclos tectónicos, volcánicos y sedimentarios del Cenozoico del sur de MendozaArgentina $\left(35^{\circ}-37^{\circ} \mathrm{S}\right.$ y $\left.69^{\circ} 30^{\prime} \mathrm{W}\right)$. Andean Geology 38, 98-218.

Combina, A., Nullo, F. \& Stephens, G. 1993. Depósitos terciarios en el pie de sierra del área Las Aucas, sur de Mendoza. In XII Congreso Geológico Argentino, Actas 2, 180-6.

ConsteniUs, K. N. 1996. Late Paleogene extensional collapse of the Cordilleran foreland fold and thrust belt. Geological Society of America Bulletin 108, 20-39.

Cooper, M. A., Addison, F. T., Alvarez, R., Coral, M., Graham, R. H., HaYward, A. B., Howe, S., Martinez, J., NaAr, J., Peñas, R., Pulham, A. J. \& TABorda, A. 1995. Basin development and tectonic history of the Llanos basin, Eastern Cordillera, and middle Magdalena Valley, Colombia. American Association of Petroleum Geologists Bulletin 79, 1421-43.

DAJCZGEwAND, D. M. 2002. Faja Plegada y Corrida de Malargüe: estilo de la deformación en Mallín Largo. Trabajo Final de Licenciatura, Facultad de Ciencias Exactas y Naturales, Departamento de Geología, Universidad de Buenos Aires, Buenos Aires, Argentina. Published thesis.

Digregorio, R. E., Gulisano, C. A., Gutiérrez PleimLING, A. R. \& MinitTi, S. A. 1984. Esquema de la evolución geodinámica de la Cuenca Neuquina y sus implicancias paleogeográficas. IX Congreso Geológico Argentino, Buenos Aires, Actas 2, 147-62.

DimiERI, L., FORTUNATTI, N. \& NULLO, F. 2005. Estructura duplex plegada en el frente montañoso de la Cordillera Principal, Río Atuel, provincia de Mendoza. Revista de la Asociación Geológica Argentina 60, 644-50.

Fennell, L. M., Folguera, A., NAIPAUER, M., Gianni, G., Rojas Vera, E., BotTesi, G. \& RAmos, V. A. 2015. Cretaceous deformation of the southern Central Andes: synorogenic growth strata in the Neuquen Group $\left(35^{\circ}\right.$ $\left.30^{\prime}-37^{\circ} \mathrm{S}\right)$. Basin Research. doi: 10.1111/bre.12135.

Folguera, A., BotTesi, G., Duddy, I., MARTÍN-GONZÁleZ, F., ORTS, D., SAgripanti, L., Vera, E. R. \& Ramos, V. A. 2015. Exhumation of the Neuquén Basin in the southern Central Andes (Malargüe fold and thrust belt) from field data and low-temperature thermochronology. Journal of South American Earth Sciences 64, 381-98.

Folguera, A., Naranjo, J. A., Orihashi, Y., Sumino, H., NagaO, K., Polanco, E. \& Ramos, V. A. 2009. Retroarc volcanism in the northern San Rafael Block (34 ${ }^{\circ}$ $\left.35^{\circ} 30^{\prime} \mathrm{S}\right)$, southern Central Andes: occurrence, age, and tectonic setting. Journal of Volcanology and Geothermal Research 186, 169-85.

Folguera, A. \& RAmos, V. A. 2011. Repeated eastward shifts of arc magmatism in the Southern Andes: A revision to the long-term pattern of Andean uplift and magmatism. Journal of South American Earth Sciences 32, 531-46.

GERTH, E. 1931. La estructura geológica de la Cordillera Argentina entre el río Grande y río Diamante en el sur de la provincia de Mendoza. Academia Nacional de Ciencias, Actas 10, 125-72.

Giambiagi, L. B., Bechis, F., García, V. \& Clark, A. H. 2008. Temporal and spatial relationships of thickand thin-skinned deformation: a case study from the Malargüe fold-and-thrust belt, southern Central Andes. Tectonophysics 459, 123-39.

Giambiagi, L., Ghiglione, M., Cristallini, E. \& Bottesi, G. 2009. Kinematic models of basement/cover interaction: insights from the Malargüe fold and thrust belt, Mendoza, Argentina. Journal of Structural Geology 31, 1443-57.

Giambiagi, L., Mescua, J., Bechis, F., Tassara, A. \& HoKe, G. 2012. Thrust belts of the southern Central Andes: along-strike variations in shortening, topography, crustal geometry, and denudation. Geological Society of America Bulletin 124, 1339-51.

Giampaoli, P., Ramirez, J. \& Gait, M. 2005. Estilos de Entrampamiento en la Faja Plegada y Fallada de Malargüe. In Las Trampas de Hidrocarburos en las Cuencas Productivas de Argentina, Simposio VI Congreso de Exploración y Desarrollo de Hidrocarburos, IAPG (eds E. Kozlowski, G. Vergani \& A. Boll), pp. 121-40. Buenos Aires, Argentina.

GulisAnO, C. A. \& Gutiérrez Pleimling, A. R. 1994. The Jurassic of the Neuquén Basin, Mendoza Province. Field Guide. Asociación Geológica Argentina, Serie E 3, $103 \mathrm{pp}$.

Horton, B. K. \& Fuentes, F. 2016. Sedimentary record of plate coupling and decoupling during growth of the Andes. Geology, published online June, 2016. doi: 10.1130/G37918.1. 
KAY, S. M., BuRnS, M. \& COPElAnd, P. 2006. Upper Cretaceous to Holocene magmatism and evidence for transient Miocene shallowing of the Andean subduction zone under the northern Neuquén Basin. In Evolution of an Andean Margin: A Tectonic and Magmatic View from the Andes to the Neuquén Basin $\left(35-39^{\circ}\right.$ S) (eds. S. M. Kay \& V. A. Ramos), pp. 1960. Geological Society of America, Special Paper no. 407.

Kley, J., Rossello, E. A., Monaldi, C. R. \& Habighorst, B. 2005. Seismic and field evidence for selective inversion of Cretaceous normal faults, Salta rift, northwest Argentina. Tectonophysics 399, 155-72.

KOZLOWSKI, E. 1984. Interpretación estructural de la Cuchilla de la Tristeza, Provincia de Mendoza. In $I X$ Congreso Geológico Argentino, Actas v. II, San Carlos de Bariloche, Argentina, pp. 381-95.

Kozlowski, E., BALDI, J. \& MAncilla, O. 1981. Plano Geológico Río Diamante - Río Atuel. Buenos Aires: YPF Internal Report.

Kozlowski, E., CruZ, C., CONDAT, P. \& MANCEDA, R. 1989. Informe Geológico Malargüe Occidental, Cuenca Neuquina, provincia de Mendoza. Buenos Aires: YPF Internal Report and Map.

Kozlowski, E., Cruz, C. E., Manceda, R. \& Condat, P. 1990. Estructuración distensiva en los Andes Surmendocinos, Argentina. XI Congreso Geológico Argentino, Actas 2, 23-6.

Kozlowski, E., Cruz, C. \& Sylwan, C. 1997. Modelo exploratorio en la faja corrida de la Cuenca Neuquina, Argentina. Sexto Simposio Bolivariano "Exploración Petrolera en las Cuencas Subandinas". Memorias 1, $15-31$.

Kraemer, P., Silvestro, J., Achilli, F. \& Brinkworth, W. 2011. Kinematics of a hybrid thick-thin-skinned fold and thrust belt recorded in Neogene syntectonic wedgetop basins, southern central Andes between $35^{\circ}$ and $36^{\circ}$ S, Malargüe, Argentina. In Thrust Fault-Related Folding (eds K. McClay, J. Shaw, \& J. Suppe), pp. 245-70. American Association of Petroleum Geologists, Memoir no. 94.

Lanés, S., Giambiagi, L., Bechis, F. \& TuniK, M. 2008. Late Triassic - Early Jurassic successions of the Atuel depocenter: sequence stratigraphy and tectonic controls. Revista de la Asociación Geológica Argentina 63, 53448.

Legarreta, L., Kokogian, D. A. \& Boggetti, D. A. 1989. Depositional sequences of the Malargüe Group (Upper Cretaceous-Lower Tertiary), Neuquén Basin, Argentina. Cretaceous Research 10, 337-56.

LEGARRETA, L., KozlowsKi, E. \& Boll, A. 1981. Esquema estratigráfico y distribución de facies del Gr. Mendoza en el ámbito del sur mendocino de la Cuenca Neuquina. VIII Congreso Geológico Argentino (San Luis), Actas 3 , 389-409.

LEgARRETA, L. \& UlianA, M. A. 1991. Jurassic-Cretaceous marine oscillations and geometry of back-arc basin fill, central Argentine Andes. In Sedimentation, Tectonics and Eustasy: Sea-Level Changes at Active Margins (ed. D. I. M. Macdonald), pp. 429-50. International Association of Sedimentologists, Special Publication no. 12.

MANCEDA, R. \& FIGUEROA, D. 1995. Inversion of the Mesozoic Neuquén rift in the Malargüe fold and thrust belt, Mendoza, Argentina. In Petroleum Basins of South America (eds J. Tankard, R. Suárez Soruco \& H. J. Welsink), pp. 369-82. American Association of Petroleum Geologists, Memoir no. 62.
MCClAY, K. R. 1995. The geometries and kinematics of inverted fault systems: a review of analogue model studies. In Basin Inversion (eds J. G. Buchanan \& P. G. Buchanan), pp. 97-118. Geological Society of London, Special Publication no. 88.

Mescua, J. F. \& Giambiagi, L. B. 2012. Fault inversion vs. new thrust generation. A case study in the Malargüe fold-and-thrust belt, Andes of Argentina. Journal of Structural Geology 35, 51-63.

Mescua, J. F., Giambiagi, L. B. \& Ramos, V. A. 2013. Late Cretaceous uplift in the Malargüe fold-and-thrust belt $\left(35^{\circ} \mathrm{S}\right)$, southern Central Andes of Argentina and Chile. Andean Geology 40, 102-16.

Mombru, C. \& BetTini, F. 1975. Relevamiento geológico entre el Arroyo Pequenco y el Río Atuel, Depto. Malargüe, Mendoza. Buenos Aires: YPF Internal Report.

Perez, N. D., Horton, B. K., McQuarrie, N., StÜBner, K. \& EHLERS, T. A. 2016. Andean shortening, inversion, and exhumation associated with thin- and thick-skinned deformation in southern Peru. Geological Magazine, published online 3 June 2016. doi: 10.1017/S0016756816000121.

Ploskiewicz, J. V. 1987. Las zonas triangulares de la faja fallada y plegada de la Cuenca Neuquina, Argentina. $X$ Congreso Geológico Argentino 10, 177-80.

Ploskiewicz, J. V. 1993. Yacimiento Puesto Rojas. In Geología y Recursos Naturales de Mendoza, XII ${ }^{\circ}$ Congreso Geológico Argentino y II Congreso de Exploración de Hidrocarburos, Mendoza, Relatorio. III (15) (ed. V. A. Ramos), pp. 447-50.

PloskieWICZ, V. \& GORROÑO, R. 1988. Tectónica de inyección salina en la falla y plegada del sur de Mendoza. Boletín de Informaciones Petroleras, Tercera Epoca 5 (14), 29-34. Buenos Aires, Argentina.

Ramos, V. A. 1999. Plate tectonic setting of the Andean Cordillera. Episodes 22, 183-90.

Ramos, V. A., Cegarra, M. \& CRistallini, E. 1996. Cenozoic tectonics of the High Andes of west-central Argentina $\left(30^{\circ}-36^{\circ} \mathrm{S}\right.$ latitude). Tectonophysics 259, 185-200.

Ramos, V. A. \& FolguerA, A. 2005. Tectonic evolution of the Andes of Neuquén: constraints derived from the magmatic arc and foreland deformation. In The Neuquén Basin: A Case Study in Sequence Stratigraphy and Basin Dynamics (eds L. Spalletti, G. Veiga, E. Schwarz \& J. Howell), pp. 15-35. Geological Society of London, Special Publication no. 252.

RAMOS, V. A. \& KAY, S. 2006. Overview of the tectonic evolution of the southern Central Andes of Mendoza and Neuquén ( $35^{\circ}-39^{\circ} \mathrm{S}$ latitude). In Evolution of an Andean Margin: A Tectonic and Magmatic View from the Andes to the Neuquén Basin ( $35^{\circ}-39^{\circ} \mathrm{S}$ latitude) (eds S. M. Kay \& V. A. Ramos), pp. 1-17. Geological Society of America, Special Paper no. 407.

Tickyj, H., Rodríguez Raising, M., Cingolani, C., Alfaro, M. \& URIZ, N. 2009. Graptolitos Ordovícicos en el sur de la Cordillera Frontal de Mendoza, Argentina. Revista de la Asociación Geológica Argentina 64, 295-302.

Tunik, M., Folguera, A., Naipauer, M., Pimentel, M. \& RAMOS, V. A. 2010. Early uplift and orogenic deformation in the Neuquén Basin: constraints on the Andean uplift from $\mathrm{U}-\mathrm{Pb}$ and $\mathrm{Hf}$ isotopic data of detrital zircons. Tectonophysics 489, 258-73.

TURIENZO, M. 2010. Structural style of the Malargüe fold and-thrust belt at the Diamante River area $\left(34^{\circ} 30^{\prime}-\right.$ $34^{\circ} 50^{\prime} \mathrm{S}$ ) and its linkage with the Cordillera Frontal Andes of central Argentina. Journal of South American Earth Sciences 29, 537-56. 
Turienzo, M., Dimieri, L., Frisicale, C., Araujo, V. \& SÁNCHEZ, N. 2012. Cenozoic structural evolution of the Argentinean Andes at $34^{\circ} 40^{\prime} \mathrm{S}$ : a close relationship between thick and thin-skinned deformation. Andean Geology 39, 317-57.

Vergani, G. D., TANKard, A. J., Belotti, H. J. \& WELSINK, H. J. 1995. Tectonic evolution and paleogeography of the Neuquén basin, Argentina. In Petroleum Basins of South America (eds J. Tankard, R. Suarez Soruco \& H. J. Welsink), pp. 383-402.
American Association of Petroleum Geologists, Memoir no. 62.

VolKheimer, W. 1978. Descripción geológica de la hoja 27b, Cerro Sosneado, Provincia de Mendoza. SEGEMAR 151, 85 pp.

Williams, G. D., Powell, C. M. \& CoOper, M. A. 1989. Geometry and kinematics of inversion tectonics. In Inversion Tectonics (eds M. A. Cooper \& G. D. Williams), pp. 3-15. Geological Society of London, Special Publication no. 44. 